\title{
Assessment of Blood Metabolites Disorders and Related Pathological Risk Factors in Cows of Constantine Region, Algeria
}

\author{
Adel MAMMERI ${ }^{1 *}$, Fatima Zohra KAYOUECHE ${ }^{2}$, Loubna DENHADJI ${ }^{2}$ and Abdelmalek BENMAKHLOUF ${ }^{2}$ \\ ${ }^{1}$ University of M'Sila, Faculty of Sciences, Department of Agronomic Sciences, University Pole, BP 166, \\ M'Sila 028000, Algeria \\ ${ }^{2}$ University of Frères Mentouri, Constantine 1, Institute of Veterinary Sciences, El'Khroub, 25100, BP 325, \\ Route of Ain EL Bey, 27017 Constantine, Algeria \\ *corresponding author: adel.mammeri@univ-msila.dz \\ Bulletin UASVM Veterinary Medicine 77(2)/2020 \\ Print ISSN 1843-5270; Electronic ISSN 1843-5378 \\ doi:10.15835/buasvmcn-vm:2020.0006
}

\begin{abstract}
The aim of the present study is to evaluate some blood metabolites and to predict the occurence of nutritional imbalances affecting milk production and health status of cows. It included 180 dairy cows of five different breeds reared in five farms of Constantine Governorate. The biochemical analyzes via Technicon RA-X and RA1000 autoanalyzers focused on: calcium, phosphorus, total proteins, lipids, glucose and creatinine.It results that hyperphosphatemia ( $>65 \mathrm{mg} / \mathrm{L}$ ) was clear in cows of farms 1 and 2 and moderate in those of farm 3; moderate hypocalcemia $(<97 \mathrm{mg} / \mathrm{L})$ in cows of farms $1,2,3$ and 4 ; moderate hypoproteinemia $(<67 \mathrm{~g} / \mathrm{L})$ in farms 2 and 5; moderate hyperproteinemia (>74.6 g/L) in farms 3 and 4, a clear hypercholesterolemia in whole farms. The significant differences $(\mathrm{P}<0.01)$ via ANOVA test between farms, suggest variability of management methods, feeding practices and health status of cows.
\end{abstract}

Keywords: biochemical profiles, hypocalcemia, dairy cows, Constantine, Algeria.

\section{Introduction}

The physiological and nutritional status of cows can be evaluated using the analysis of blood biochemical parameters (Ashmawy, 2015). The main blood parameters reveal variations according to breed, season and physiological stage of cows (Benedet et al., 2020). Commonly, gestation is a critical phase for cows' health and milk production. Calcium (Ca) and phosphorus (P) levels are among the most changing parameters, as principal nutrients, during pregnancy and lactation (Hadzimusic and Krnic, 2012).

According to Cai et al. (2018), the dairy cows (DCs) with subclinical hypocalcemia had significantly lower serum levels of $\mathrm{Ca}, \mathrm{K}, \mathrm{Na}$,
$\mathrm{Mg}, \mathrm{Cl}, 1,25(\mathrm{OH})_{2} \mathrm{D}_{3}$ and glucose (GLC) and had significantly higher levels of serum $\mathrm{P}$, nonesterified fatty acids and $\beta$-hydroxybutyrate than their healthy counterparts on calving day also authors concluded a significant association between subclinical hypocalcemia and risk of the development of ketosis and fatty liver.

Furthermore, variations of serum $\mathrm{Ca}, \mathrm{Mg}$, urea (URE), aspartate amino-transferase and Cholesterol (CLT) concentrations was observed in cows affected by dystocia, retained placenta, downer cow syndrome, vaginal prolapse and abortion (Molefe and Mwanza, 2019). Recently, Coskun et al. (2020) observed changes in $\mathrm{K}, \mathrm{Cu}, \mathrm{Na}$ and $\mathrm{Ca}$ levels in blood of calves with sepsis; authors con- 
cluded that monitoring changes in levels of these mineral elements would be beneficial during the treatment of calves with sepsis. However, seasonal and physiologic variations have to be taken into consideration for the correct interpretation of serum chemistry and elements status in cattle (Yokus and Cakir , 2006).

Thus, assessment of crucial blood parameters would help both of breeders and treating veterinarians to predict occurrence of some metabolic disorders such as hypocalcemia and other diseases related to nutritional status imbalances. Moreover, it would help farms' managers to have a periodical global overviews of feeds intake values and desiquilibrium or detect eventual parasitism reliable to yiels diminish of DCs.Within this background, the aim of the present study is to assess and compare the main blood metabolites in a sample of DCs reared in Constantine Governorate then discuss the associated pathological risk factors in the context of dominant physiological and pathological values reported by several authors.

\section{Material and methods \\ Study area}

Constantine Governorate is located between latitude of $36^{\circ} 17^{\prime}$ and longitude of $6^{\circ} 37^{\prime}$ in the center of eastern Algeria, at an altitude of $660 \mathrm{~m}$ above the level of the Mediterranean. It includes 12 municipalities, with a total area of $2,297.2 \mathrm{~km}^{2}$. It has a total population estimated at 938,475 inhabitants with a density of 400 inhabitants per $\mathrm{km}^{2}$. This region is characterized by a Mediterranean climate with a hot and dry summer and a cold and wet winter. In summer, the temperature is within marge of $25-40^{\circ} \mathrm{C}$, while in winter, it ranges between $0^{\circ}$ and $12^{\circ} \mathrm{C}$. The annual rainfall varies between $500 \mathrm{~mm}$ and $700 \mathrm{~mm}$ for 20 days per year (ANDI, 2013).

The region of Constantine has an agricultural vocation, with a useful agricultural area (UAA) of

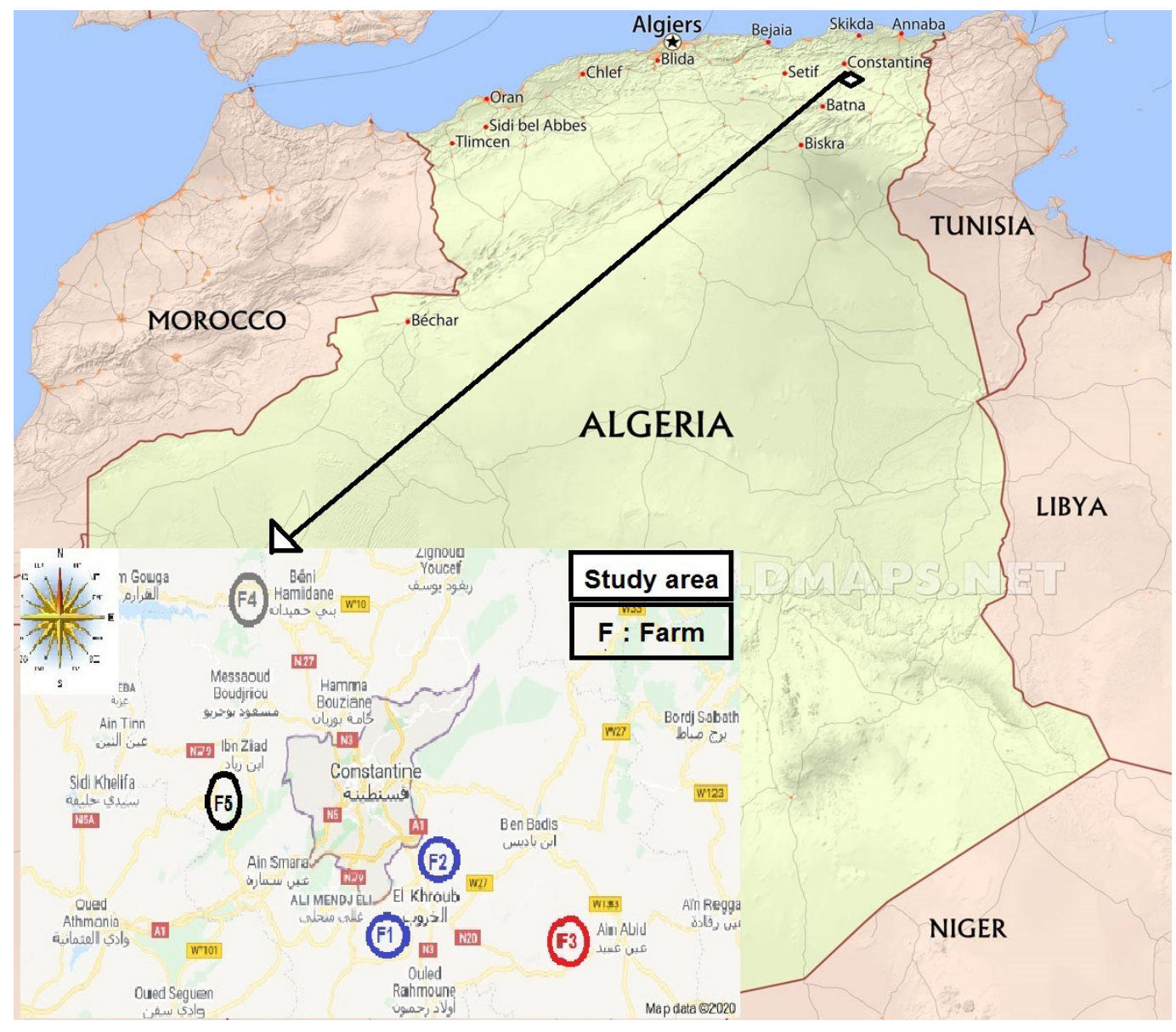

Figure1: Distribution of surveyed farms in study area 
approximately 131,096 ha. The most important productions are cattle then sheep meats, poultry and dairy production (ANDI, 2013). The study area includes four municipalities: El'Khroub, with a UAA of 18,012 ha and a cattle herd of 3,154 Heads (Hs) including 1,430 DCs, reared in 254 farms (DAS, Constantine, 2011); Ain Abid municipality where the UAA is equal to 23,925 ha with a total cattle herd of 8,003 Hs including 3,658 DCs, acquired by 545 registered breeders (DAS, Constantine, 2015); Béni Hamidane and Ibn Ziad municipalities which hold a significant part of milk production in the region of Constantine (MARD, 2014) (Figure 1).

\section{Study design and animals sampling}

The whole study was carried out from March to October; 2018.Blood samples were collected during spring period from April to June, 2018. A total of 180 clinically healthy DCs of different age classes and belonging to five different introduced breeds (Table 1) were sampled randomly among five farms (Fs) of study area (Figure 1).The global sample included DCs at several physiological stages: early dry cows; close-up dry cows; fresh cows and whole pregnancy stages; primiparous and multiparous. Cows' age ranged between 2 and 10 years old. Results interpretation and discussion was based on limit thresholds of assessed metabolites that are defined as risk factors for occurrence of related disorders or diseases in DCs. For more reliability, we tried as possible to use thresholds emanating from studies carried out on breeds similar to those treated in our study (Table 1). Certain authors did not give details concerning the breeds composing their samples (Table 4), but much more, they specified the pathophysiological circumstances of occurrence of metabolic disorders in DCs.

\section{Specimen collection and assessment of biochemical profiles}

All experiments have been conducted in accordance with relevant national and international legislations on the use of animals for research. The blood samples were taken from the jugular vein, in $10 \mathrm{ml}$ dry and heparinized sterile vacutainer tubes. After identification, blood samples were transported into low temperature cooler to the laboratory then centrifuged at 3000 round per $\min$ for $10 \mathrm{~min}$. The sera were stored at $-20^{\circ} \mathrm{C}$ until analyzed. The analyzes were performed in the Central Laboratory of Biochemistry at the University Hospital of Constantine (CHU). As it is clear on Table 2, for uncontrollable circumstances, we have not fulfilled the complete analyzes on each farm and sometimes few results are missing for a given parameter.The sera were thawed before the analyzes.All assays were accomplished using Technicon RA-X and Technicon RA-1000 autoanalyzers, testing multiple samples in sequence.

Control sera and calibrators were used to monitor the performance of assay procedures: SPINTROL H Calibrator, SPINTROL H Normal and Pathologic (Ref. 1002011, 1002120 and 1002210). Then the devices were adjusted via a standard bovine serum of known value which was used as a second control test.SPINREACT kits (Spain) have a sensitivity of $1 \mathrm{mg} / \mathrm{dL}$.Clean disposable pipette tips were used for dispensation of reagents.Concentration in the test samples was determined according to manufacturer's instructions for each kit.

\section{Data collection and analyses}

When calculating means and variances, Excel windows XP 2007 software was used. The collected data have been coded then entered into the Epi info software version 7.1.5 (2015) to: determine

Table 1: Distribution of sampled DCs on study area

\begin{tabular}{ccccccc}
\hline Municipalities & \multicolumn{2}{c}{ El'Khroub } & Ain Abid & $\begin{array}{c}\text { Béni } \\
\text { Hamidane }\end{array}$ & Ibn Ziad & Total \\
\hline Farms & $\mathrm{F} 1$ & $\mathrm{~F} 2$ & $\mathrm{~F} 3$ & $\mathrm{~F} 4$ & $\mathrm{F5}$ & 05 \\
\hline Sampled DCs (Hs) & 26 & 58 & 37 & 31 & 28 & 180 \\
\hline Breeds (Hs) & $\begin{array}{c}F F B P(24) \\
F F R P(2)\end{array}$ & $F F B P$ & $\begin{array}{c}F F B P(26) \\
\text { TAR (11) }\end{array}$ & HOL & FLE & \\
\hline
\end{tabular}

FFBP: French Fresian Black-Pied, FFRP: French Fresian Red-Pied; TAR: Tarentaise, HOL: Holstein, FLE: Fleckvieh 
frequencies for qualitative variables and means (Ms); standard deviations (SDs) for quantitative variables; to compare percentages and Ms (ANOVA). For percentage comparisons, Epi Info software provides a table of the distributions of the observations and then the corrected chi-square, the Mantel-Hoenszel chi-square and the Yates corrected chi-square for tables with 2 variables. It signals the existence of a theoretical number of less than 5 and proposes for the $2 \times 2$ tables an exact Fisher test. For means comparisons, Epi Info software first provides a table with the number of observations per group, the mean, the variance, the standard deviation, the smallest value, the largest value and the mode of each distribution. It performs the Student test when it comes to the comparison of 2 groups ( $<30$ ), otherwise an ANOVA ( $F$ from Snedecor) with a test of homogeneity of variances from Barlett and the non-parametric test from Mann- Whitney (for more than 2 groups) or the non-parametric test of Kruskall-Wallis (for more than 2 groups).The significance level is $\mathrm{p} \leq$ 0.05 .

Table 2: Serum parameters, analysis methods and samples performed in study area

\section{Results and discussions Variability of serum metabolites Ms depending on Fs Incomplete mineral profile}

For calcemia, the highest $\mathrm{M}$ value corresponded to F2, F1 and F4, respectively, while the lowest one were observed in F3 (Table 3). The average values of sera Ca revealed in the four Fs, were lower than the physiological values range reported by Bradford et al. (2020); (97-124 mg/L) (Table 4) and Brugère-Picoux (1995); (112 $\mathrm{mg} / \mathrm{L}$ ). Althought, surveyed DCs did not reach the values making it possible to reveal at least one of the three levels of clinical hypocalcemia reported by Robert etThrelfall (2007) (Ca < 40-77 $\mathrm{mg} / \mathrm{L}$ ) (Table 4). This would indicate existence of a moderate hypocalcemia in sampled DCs which would be related to deficient rations in Ca or to a side effect of lack of Mg.

Underwood and Shuttle (1999) report several causes for hypocalcemia, among which: poor gastrointestinal absorption and insufficient bone resorption of Ca. According to Barnouin and

Table 2: Serum parameters, analysis methods and samples performed in study area

Blood metabolites

Methods of analyzes (SPINREACT kits, Spain)
Total tests

(n)

\begin{tabular}{lll}
\hline Calcium (Ca) & $\begin{array}{l}\text { Technicon RA with use of 8-hydroxyquinoline to } \\
\text { eliminate interférences due to Mg }\end{array}$ & 152 \\
\hline $\begin{array}{l}\text { Inorganic } \\
\text { Phosphorus (P) }\end{array}$ & Colorimetric dosage. Reading is done at 340 nm & 152 \\
\hline Glucose (GLC) & Colorimetric enzymatic dosage.Reading is done at 500-520 nm & 180 \\
\hline Urea (URE) & Enzymatic dosage via Urease- GLDHc. Reading is done at 340 nm & 180 \\
\hline Total proteins (TP) & Biuret method. Reading is done at 340 nm & 180 \\
\hline Albumin (ALB) & Colorimetric dosage via bromocresol green & 115 \\
\hline Globulin (GLB) & Evaluated by difference between TP and ALB levels & 115 \\
\hline Creatinine (CRT) & $\begin{array}{l}\text { Based on the reaction of picric acid with creatinine in } \\
\text { an alkaline medium.Reading is done at 500 nm }\end{array}$ & 180 \\
\hline Cholesterol (CLT) & $\begin{array}{l}\text { Formation of a colored quinoneimine } \\
\text { complex. Reading is done at 500 nm }\end{array}$ & 180 \\
\hline Triglycerides (TG) & $\begin{array}{l}\text { Colorimetric enzymatic dosage and formation of pink } \\
\text { colored quinoneimine. Reading is done at 520 nm }\end{array}$ \\
\hline
\end{tabular}

Gitelman, 1967, b. Payne et al., 1970. c. Urease-glutamate dehydrogenase 
Chassagne (1991), the risk for both milk fever and placental retention appears to be maximum with old DCs fed diets rich in green fodder (fresh or ensiled) and in $\mathrm{Ca}$, and poor in cereals in the prepartum period. Allen, (2015) highlights that DCs will secrete 20-30 g of Ca in the production of colostrum and milk in the early stages of lactation, which would induce decline of serum Ca levels from a normal of $85-100 \mathrm{mg} / \mathrm{L}$ to lesser than 75 $\mathrm{mg} / \mathrm{L}$. Furthermore, Cai et al. (2018) reports that subclinical hypocalcemia was associated with a risk of the development of ketosis and fatty liver.

The phosphatemia average values obtained from F1 and F2 (Table 3) were higher than normal range reported by Bradford et al. (2020); (56-65 mg/L) (Table 4), comparatively, F3 DCs were slightly higher than the upper value, while F4 DCs had the lowest values and were within the cited normal range (Table 3). For the same region, the results obtained from the surveyed DCs vary significantly throught Fs.

Regarding the high phosphatemia average obtained from DCs of F1 and F2, it was also noted that the same Fs revealed the highest average values of GLG, CLT and TG. According to BrugerePicoux (1984), hypervitaminosis D can cause hyperphosphatemia. It is likely that food rations in F1 and F2 were exceptionally rich in P. In fact, during survey, the feeding of DCs of F1 and F2 consisted of a basic ration including corn silage, vetch-oat hay and a 25\% concentrate of barley. Barley is known to be rich in P (Jarrige, 1988; Wolter, 1994; 1997).

Also, Payne et al. (1970) draw attention to a rise in blood $\mathrm{P}$ in grazing animals caused by the spread of phosphate enriched fertilizer. This suggests that the pasture available to the cattle in F1 and F2 would be subject to the application of fertilizers in pasture lands.

The average $\mathrm{Ca}$ : $\mathrm{P}$ ratios $(\mathrm{Ca} / \mathrm{P})$ were rising, respectively: 1 (F1); 1.31 (F2); 1.31 (F3) and 1,58 (F4). They were within ratio range reported by literature (Table 4).

\section{Nitrogen parameters}

Except for F1, the average values for TP recorded in F2 and F5 (Table 3) were slightly lower than the normal range reported by Bradford et al. (2020) for TP; (67-74.6 g/L), while they were slightly higher in F3 and F4 than the cited upper threshold (Table 3).

Several causes had been reported by literature regarding disorders of TP in DCs (Table 4). Lower values of serum TP would be concomitant to a slight undernutrition with lack of nitrogen (Barnouin

Table 3: Ms and SDs of blood metabolites in DCs of the surveyed Fs

\begin{tabular}{|c|c|c|c|c|c|c|c|c|c|c|}
\hline \multirow{5}{*}{ SP } & \multicolumn{10}{|c|}{ Fs and breeds composition (\%) } \\
\hline & \multicolumn{2}{|c|}{ F1 } & \multicolumn{2}{|c|}{ F2 } & \multicolumn{2}{|c|}{ F3 } & \multicolumn{2}{|c|}{ F4 } & \multicolumn{2}{|l|}{ F5 } \\
\hline & \multirow{2}{*}{\multicolumn{2}{|c|}{$\begin{array}{l}F F B P(\mathbf{9 2 . 3 0} \%) \\
F F R P(07.70 \%)\end{array}$}} & \multirow{2}{*}{\multicolumn{2}{|c|}{$\begin{array}{c}F F B P \\
(\mathbf{1 0 0} \%)\end{array}$}} & \multirow{2}{*}{\multicolumn{2}{|c|}{$\begin{array}{l}F F B P(70.27 \%) \\
T A R \quad(29.73 \%)\end{array}$}} & \multirow{2}{*}{\multicolumn{2}{|c|}{$\begin{array}{c}H O L \\
(\mathbf{1 0 0} \%)\end{array}$}} & \multirow{2}{*}{\multicolumn{2}{|c|}{$\begin{array}{c}F L E \\
(\mathbf{1 0 0} \%)\end{array}$}} \\
\hline & & & & & & & & & & \\
\hline & $\mathbf{M}$ & SD & M & SD & M & SD & $\mathbf{M}$ & SD & M & SD \\
\hline Ca mg/L & 94.69 & 8.69 & 95.78 & 10.81 & 86.32 & 7.52 & 93.57 & 3.75 & NM & NM \\
\hline P mg/L & 94.88 & 15.14 & 72.93 & 12.21 & 65.78 & 9.71 & 59.23 & 8.11 & NM & NM \\
\hline TP g/L & 70.96 & 8.59 & 65.98 & 8.19 & 74.68 & 5.55 & 76.13 & 5.64 & 66.64 & 6.93 \\
\hline URE g/L & 0.29 & 0.11 & 0.14 & 0.09 & 0.16 & 0.04 & 0.29 & 0.07 & 0.26 & 0.04 \\
\hline ALB g/L & 31.52 & 3.43 & 27.90 & 3.12 & NM & NM & 30.29 & 2.40 & NM & NM \\
\hline GLB g/L & 39.44 & 8.79 & 39.22 & 8.52 & NM & NM & 45.84 & 5.45 & NM & NM \\
\hline CRT mg/L & 9.48 & 1.45 & 13.22 & 2.75 & 15.32 & 2.60 & 12.97 & 2.34 & 16.25 & 2.68 \\
\hline TG g/L & 0.25 & 0.09 & 0.22 & 0.14 & 0.17 & 0.05 & 0.15 & 0.06 & 0.16 & 0.11 \\
\hline CLT g/L & 1.79 & 0.74 & 2.20 & 0.53 & 1.53 & 0.25 & 1.58 & 0.35 & 1.56 & 0.42 \\
\hline GLC g/L & 0.70 & 0.10 & 0.69 & 0.16 & 0.49 & 0.09 & 0.34 & 0.09 & 0.55 & 0.12 \\
\hline
\end{tabular}

SP: Serum Parameter, NM: Not Measured 
Table 4: Summary of the main risk factors in relation to serum metabolites thresholds, associated disorders and pathologies in DCs according to relevant literature

\begin{tabular}{|c|c|c|c|c|c|}
\hline $\mathbf{S P}$ & Risk factors & $\begin{array}{c}\text { Serum } \\
\text { metabolites } \\
\text { thresholds }\end{array}$ & $\begin{array}{l}\text { Related disease/ } \\
\text { disorder (s) }\end{array}$ & $\begin{array}{l}\text { Physiological } \\
\text { common } \\
\text { stages/breeds }\end{array}$ & References \\
\hline $\mathrm{Ca}$ & $\begin{array}{l}\text { subclinical/ } \\
\text { subacute/acute } \\
\text { hypoCa }\end{array}$ & $\begin{array}{l}\text { nl: } 97-124 \\
\text { mg/L } \\
\text { anl stage 1: } \\
55-77 \mathrm{mg} / \mathrm{L} \\
\text { anl stage } 2: \\
40-60 \mathrm{mg} / \mathrm{L} \\
\text { anl stage } 3: \\
<40 \mathrm{mg} / \mathrm{L}\end{array}$ & $\begin{array}{l}\text { - ketosis } \\
\text { - fatty liver } \\
\text { - hyperphosphatemia } \\
\text { - transport tetany } \\
\text { - displaced abomasum } \\
\text { - abomasal volvulus } \\
\text { - uterine and } \\
\text { vaginal prolapses } \\
\text { - neurological disorders } \\
\text { - placental retention } \\
\text { - metritis } \\
\text { - depression and coma }\end{array}$ & $\begin{array}{l}\text { - } 4 \text { weeks } \\
\text { before calving } \\
\text { - early stages } \\
\text { of lactation } \\
\text { - common } \\
\text { in H-YDCs } \\
\text { - } \geq 3^{\text {d }} \text { lactation }\end{array}$ & $\begin{array}{l}\text { - Robert et } \\
\text { Threlfall (2007) } \\
\text { - Gourreau et } \\
\text { Bendali (2008) } \\
\text { - Constable (2014) } \\
\text { Allen, (2015) } \\
\text { - Cai et al. (2018) } \\
\text { - Bradford et al. (2020) }\end{array}$ \\
\hline \multirow{3}{*}{$\begin{array}{l}\mathrm{Ca}: \mathrm{P} \\
\text { ratios }\end{array}$} & $\begin{array}{l}\text { periparturient } \\
\text { hypoP }\end{array}$ & \multirow{2}{*}{$\begin{array}{l}\text { nl: } 56-65 \\
\text { mg/L } \\
\text { within ratio } \\
\text { range: } \\
1: 1-8: 1\end{array}$} & $\begin{array}{l}\text { - chronic renal } \\
\text { tubular disease } \\
\text { - alkalemia } \\
\text {-respiratory alkalosis }\end{array}$ & $\begin{array}{l}\text { - periparturient } \\
\text { - onset of } \\
\text { lactation } \\
\text { - H-YDCs }\end{array}$ & \multirow{3}{*}{$\begin{array}{l}\text { - Robert et } \\
\text { Threlfall (2007) } \\
\text { - Gourreau et } \\
\text { Bendali (2008) } \\
\text { - Gruenberg } \\
\text { (2014) } \\
\text { - Bradford et al. (2020) }\end{array}$} \\
\hline & hyperP & & $\begin{array}{l}\text { - periparturient } \\
\text { hypocalcemia }\end{array}$ & $\begin{array}{l}\text { - periparturient } \\
\text { - onset of } \\
\text { lactation } \\
\text { - H-YDCs }\end{array}$ & \\
\hline & $\begin{array}{l}\text { Global } \\
\text { simultaneous } \\
\text { deficiency in } \\
\text { Ca and P }\end{array}$ & $\begin{array}{l}\text { within ratio } \\
\text { range: } \\
1: 1-8: 1\end{array}$ & $\begin{array}{l}\text { - lameness } \\
\text { - osteoporosis } \\
\text { - osteomalacia } \\
\text { - stillbirth }\end{array}$ & $\begin{array}{l}\text { - periparturient } \\
\text { - H-YDCs } \\
\text { - French Cattle }\end{array}$ & \\
\hline $\mathrm{TG}$ & hyperTG & $\begin{array}{l}\mathrm{nl}: 0.20- \\
0.22 \mathrm{~g} / \mathrm{L}\end{array}$ & $\begin{array}{l}\text { - hyperlipemia } \\
\text { - hyperTG } \\
\text { - hyperCLT } \\
\text { - hypoproteinemia } \\
\text { - liver lipidosis } \\
\text { - acute hepatic } \\
\text { rupture (death) } \\
\text { - metabolic acidosis } \\
\text { - placental retention }\end{array}$ & $\begin{array}{l}\text { - H-YDCs } \\
-F F B P\end{array}$ & $\begin{array}{l}\text { - Chassagne et } \\
\text { al. (1998) } \\
\text { - Sevinc et al. (2002) } \\
\text { - Foreman (2014) }\end{array}$ \\
\hline \multirow{2}{*}{ CLT } & hyperCLT & \multirow{2}{*}{$\begin{array}{l}\mathrm{nl}: 0.8-1.2 \\
\mathrm{~g} / \mathrm{L}\end{array}$} & $\begin{array}{l}\text { - nephrotic syndrome } \\
\text { - hypothyroidism } \\
\text { - liver cirrhosis } \\
\text { - hyperlipidemia by } \\
\text { retention jaundice }\end{array}$ & - H-YDCs & - Braun et al. (1986) \\
\hline & hypoCLT & & $\begin{array}{l}\text { - cachexia } \\
\text { - hyperthyroidism }\end{array}$ & - H-YDCs & $\begin{array}{l}\text { - Braun et al.(1986) } \\
\text { - Haskell. (2008) } \\
\text { - Bradford et al. (2020) }\end{array}$ \\
\hline
\end{tabular}




\begin{tabular}{|c|c|c|c|c|c|}
\hline GLC & hypoGLC & $\begin{array}{l}\mathrm{nl}: 4.5 \\
-7.5 \mathrm{~g} / \mathrm{L}\end{array}$ & $\begin{array}{l}\text { - ketosis } \\
\text { - hepatic degeneration } \\
\text { - metritis } \\
\text { - hepatic failure } \\
\text { - endotoxic shock }\end{array}$ & $\begin{array}{l}\text {-H-YDCs } \\
\text { - French Cattle }\end{array}$ & $\begin{array}{l}\text { - Gourreau et } \\
\text { Bendali (2008) } \\
\text { - Bradford et } \\
\text { al. }(2020)\end{array}$ \\
\hline $\begin{array}{l}\text { TP, } \\
\text { ALB } \\
\text { and } \\
\text { GLB }\end{array}$ & $\begin{array}{l}\text { anhypoproteinemia } \\
\text { with hypoALB } \\
\text { and hypoGLB/ } \\
\text { hypoproteinemia } \\
\text { with hypoALB and } \\
\text { normal GLB/ } \\
\text { hypoproteinemia } \\
\text { with hypoGLB and } \\
\text { normal ALB/ } \\
\text { normal TP } \\
\text { concentration } \\
\text { with hypoALB and } \\
\text { hyperGLB/ hyperALB } \\
\text { and hypoGLB }\end{array}$ & $\begin{array}{l}\text { TP, nl: } 67- \\
74.6 \mathrm{~g} / \mathrm{L} \\
\text { ABL, nl: } \\
23-36 \mathrm{~g} / \mathrm{L} \\
\text { GLB, nl: } \\
30-40 \mathrm{~g} / \mathrm{L}\end{array}$ & $\begin{array}{l}\text { - endotoxemia } \\
\text { - vasculitis } \\
\text { - compensated } \\
\text { hemorrhage } \\
\text { - glomerulonephritis } \\
\text { - metritis } \\
\text { - protein-losing } \\
\text { enteropathy: (intestinal } \\
\text { parasitism, abomasal } \\
\text { ulceration, enteritis / } \\
\text { colitis, lymphosarcoma, } \\
\text { Johne's disease) } \\
\text { - chronic heart failure }\end{array}$ & $\begin{array}{l}\text {-H-YDCs } \\
\text {-French Cattle } \\
\text {-HOL, MTB }\end{array}$ & $\begin{array}{l}\text {-Brugère- } \\
\text { picoux (1995) } \\
\text { - Gourreau et } \\
\text { Bendali (2008) } \\
\text { - Constable et } \\
\text { al. (2017) } \\
\text { - Bradford et } \\
\text { al. }(2020)\end{array}$ \\
\hline \multirow[b]{2}{*}{ CRT } & hypoCRT & & $\begin{array}{l}\text {-starvation with loss } \\
\text { of muscle mass }\end{array}$ & & \\
\hline & hyperCRT & $\begin{array}{l}\mathrm{nl}: 10-20 \\
\mathrm{mg} / \mathrm{L}\end{array}$ & $\begin{array}{l}\text { prerenal azotemia } \\
\text { (anl: CRT < 6mg/L) } \\
\text { renal failure } \\
\text { heart failure } \\
\text { urolithialis } \\
\text { renal, ureteral and } \\
\text { urethral calculi } \\
\text { ruptured bladder } \\
\text { carcinoma of kidneys } \\
\text { or bladder } \\
\text { perirenal abcess }\end{array}$ & $\begin{array}{l}-\mathrm{H}-Y \mathrm{Y} C \mathrm{~s} \\
-H O L\end{array}$ & $\begin{array}{l}\text {-Lorin et al. } \\
\text { (2009) } \\
\text { - Bradford et } \\
\text { al. }(2020)\end{array}$ \\
\hline \multirow[t]{2}{*}{ URE } & hyperURE & \multirow[b]{2}{*}{$\begin{array}{l}\mathrm{nl}: 0.2- \\
0.3 \mathrm{~g} / \mathrm{L}\end{array}$} & $\begin{array}{l}\text { - hepatic diseases } \\
\text { - hypovolemia } \\
\text { - starvation } \\
\text { - fever }\end{array}$ & $\begin{array}{l}\text { - H-YDCs } \\
\text { - FFBP } \\
\text { - HOL } \\
\text { - MTB }\end{array}$ & $\begin{array}{l}\text {-Barnouin } \\
\text { et Paccard } \\
\text { (1988) } \\
\text {-Brugère- } \\
\text { picoux (1995) } \\
\text {-Verriele et } \\
\text { Bedouet (1999) } \\
\text { - Bradford et } \\
\text { al. (2020) }\end{array}$ \\
\hline & hypoURE & & $\begin{array}{l}\text {-displacement of } \\
\text { the abomasums } \\
\text {-liver failure }\end{array}$ & $\begin{array}{l}\text {-H-YDCs } \\
-H O L \\
-M T B\end{array}$ & $\begin{array}{l}\text {-Brugère- } \\
\text { Picoux (1995) } \\
\text { - Bradford et } \\
\text { al. }(2020)\end{array}$ \\
\hline
\end{tabular}

SP: Serum parameter, nl: normal, anl: abnormal, H-YDCs: High-yielding dairy cows, hypoCa: hypocalcemia, hypoP: hypophosphatemia, hyperP: hyperphosphatemia, hyperTG: hypertriglyceridemia, hyperCLT: hypercholesterolemia, hypoCLT: hypocholesterolemia, hypoGLC: hypoglycemia, hyperGLB: hyperglobulinemia, hypoGLB: hypoglobulinemia, hypoALB: hypoalbuminemia, hyperALB: hyperalbuminemia, hypoCRT: hypocreatininemia, hyperCRT: hypercreatininemia, hyperURE: hyperuricemia, hypoURE: hypouricemia. 
et al., 1981), which is a risk factor of several nutritional deficiencies and parasitism occurence (Brugere-Picoux, 1984). Moreover, Eckersall (2000) indicates that an increase in the blood TP levels would be a result of an inflammatory response. Since cows of F4 had the highest levels of TP simultaneoulsy to the abnormal highest average of ALB (Table 3), this would indicate a doubtful health status of DCs in F4. Bobbo et al. (2017), suggest that blood serum TP, ALB and GLB can be a mammary gland inflammation indicator.

The lowest average of serum ALB was recorded in DCs of F2, while the highest in those of F1 (Table 3). The average values of serum ALB for all assessed DCs (F1, F2 and F4) (Table $3)$ were within the normal range reported by Brugère-Picoux (1995); (23-36g/l) (Table 4) and Kalaitzakis et al. (2006); (25-51 g/L).

The average values of serum GLB for all assessed DCs (F1, F2 and F4) were at the upper limit (F1 and F2) and higher (F4) than the normal range reported by Brugère-Picoux (1995); (30-40 $\mathrm{g} / \mathrm{L}$ ) (Table 4). The global body score category of DCs and lack of hygiene procedures in barns are practices which would be related to infectious and inflammatory diseases: mastitis, lameless, arthritis, etc... and consequently, to immune reactions.

The lowest average values of blood URE were found in DCs of F2 and F3, which were lower than normal values range reported by Bradford et al. (2020); 0.2-0.3 g/L, while those of F1, F4 and F5 were within normal values range (Table 3 ). Verite et al. (1995) report that hypouricemia in cattle is the result of being under-nourished in nitrogen in addition to a reduction in feed efficiency. Payne et al. (1970) and Pelletier et al. (1985) suggest that an increase of URE occurs in grazing animals, whereas Ferrando (1971) considers a high consumption of crude protein or high rates of ruminal hydrolysis as possible causes. Verite et al. (1995), proposes a poor nitrogen/energy balance as a cause of hyperuricemia.

\section{CRT profile}

The lowest average value for creatininemia corresponded to DCs of F1, which was slighly lower than the normal values range reported by Bradford et al. (2020); 10-20 mg/L. However, the average values recorded for F2, F3, F4 and F5 were within normality. Different diseases and disorders had been related to serum CRT imbalance in DCs (Table 4). Even when sporadic cases of CRT imbalance appear, it is difficult to generalize this on the health status of the whole dairy herd. A coherent conclusion could not be drawn considering serum CRT, especially that its reference intervals are not very common. Several authors report that creatininemia is independent of dietary and physiological factors (Rowlands et al., 1980; Wolter, 1997).

\section{Lipid profile}

Except for F2, the average sera TG values were lower for DCs of F3, F4 and F5, and higher for DCs of F1, than normality interval reported by Sevinc et al. (2002) (0.20-0.22 g/L). TG levels in DCs are relatively low because of their use in the synthesis of milk fat.Hypertriglyceridemia is considered as a risk factor for complexe and interfered metabolic disoders (Table 4). The dosage of serum TG in combination with $\beta$ hydroxybutyrate and free fatty acids reflect the degree of lipomobilization and the possibility of the development of fatty liver (Djokovic, 2012).

For sera CLT average values, the whole Fs revealed a strongly higher values, especillay for $\mathrm{F} 2$ and $\mathrm{F} 1$, with comparison to normality values range reported by Bradford et al. (2020); 0.8-1.2 $\mathrm{g} / \mathrm{L}$. They were also upper to the normal values of: (1.41 g/L) reported by Sevinc et al., (2002); and by Brugère-picoux (1995). Sommer and Marx (1969) recommend the determination of total CLT, combined with that of ASAT, eight weeks before calving, to detect hepatic disorders encountered in DCs in the postpartum period.

\section{GLC profile}

The highest average values were recorded in DCs of F1 and F2, respectively. F4 had the lowest value (Tables 3 ). With comparison to the normal values reported by Bradford et al. (2020); (4.5-7.5 $\mathrm{g} / \mathrm{L}$ ) and Verriele et Bedouet (1999); (0.5-0.7 g/L), only DCs of F4 had hypoglycemia, while other DCs were within limits of normality. Hypoglycemia in DCs of F4 would be due to: an insufficient energy intake, a feed ration poor in glucoformative substrates probably linked to a deficiency in cobalt. The DCs of F4 are mainly first-calf heifers and if the hypoglycemia is not properly corrected, it could cause infertility in the future as reported by Rowlands et al. (1980) and Wolter (1997). Thus, the feeding management should ensure sparing of GLC availability to support fertility 
in DCs after meeting other requirements of the animals (Qureshi et al., 2016).

\section{Variability of serum metabolites averages} for whole Fs

The average values for DCs of the five Fs were abnormal for incomplete mineral profile (Table 5).The Ca average value was lower than normal values range reported by Bradford et al. (2020) (Table 4) and Brugère-Picoux (1995), revealing thus a global moderate hypocalcemia in the surveyed DCs $(n=152)$. Inversly, the phosphatemia average values obtained from the whole Fs (Table 5) were clearly higher than normal range reported by Bradford et al. (2020) (Table 4). Despite these results, the hyperphosphatemia observed in the same DCs group $(n=152)$ did not affect the global Ca: $P$ ratio (1.28) which was within normality range. Soch et al. (2010) report that mineral balance is influenced of breeds and especially by the feeding during year. Thrall et al. (2012) show that hyperphosphatemia has nearly constant association with renal failure, while moderate hypocalcemia is more common with chronic than acute renal failure in cattle. According to the same authors, hypocalcemia would be due to an increase in serum $P$ level or a decrease in serum ALB level, also the decreased

Table 5: Ms and SDs of the serum parameters of surveyed DCs in whole Fs

\begin{tabular}{lccc}
\hline \multicolumn{1}{c}{ SP } & M & SD & n \\
\hline Ca mg/L & 92.86 & 9.39 & 152 \\
\hline P mg/L & 72.24 & 16.20 & 152 \\
\hline PT g/L & 70.31 & 8.28 & 180 \\
\hline URE g/L & 0.21 & 0.10 & 180 \\
\hline ALB g/L & 28.58 & 5.70 & 115 \\
\hline GLB g/L & 41.05 & 8.34 & 115 \\
\hline CRT mg/L & 13.56 & 3.21 & 180 \\
\hline TG g/L & 0.20 & 0.11 & 179 \\
\hline CLT g/L & 1.80 & 0.56 & 180 \\
\hline GLC g/L & 0.57 & 0.18 & 180 \\
\hline
\end{tabular}

SP: Serum Parameter, n: Number of DCs serum concentration of vitamin D contributes to hypocalcemia and hyperparathroidism.

The average GLB value for DCs of F1, F2 and F 4 (41.05 g/L) (Table 5) was slighly higher than range reported by Brugère-Picoux (1995) (Table 4). Despite the diversity of breeds, the whole Fs presented a very high average of sera CLT $(n=180)$ (Table 5).For all Fs, cholesterolenemia average was upper to the normality values reported by Bradford et al. (2020); Sevinc et al., (2002) and Brugère-picoux (1995). According to Boukhechem et al. (2019), the areas allocated to the forage in Algeria, represents a small proportion of (34.5\%) compared to the agricultural area in the possession of these farms, thus (44.8\%) of farmers rely on the concentrates to compensate lack of grazing areas useful for more balanced rationing for DCs. Thrall et al. (2012) report that hypercholesterolemia is seen with the nephrotic syndrome, it had been associated with increased hepatic production of lipoproteins, defective lipolysis of lipoproteins, and decreased conversion of CLT into bile acids. Our results are in concordance wih those of Bachir Pacha et al. (2016) whom reported that among bovine emergency diseases in northen Algeria, metabolic related disorders are frequent, especially: retained placenta, lameness, hypocalcemia and hypomagnesemia.

Table 6: Application of ANOVA test on the Ms of the serum parameters for the accessed DCs

\begin{tabular}{lccc}
\hline \multicolumn{1}{c}{ SP } & Sampled Fs & \multicolumn{1}{c}{$\mathbf{P}$} & Significance $^{\mathbf{a}}$ \\
\hline $\mathbf{C a}$ & $1,2,3,4$ & $<0.01$ & Sig. \\
\hline $\mathbf{P}$ & $1,2,3,4$ & $<0.01$ & Sig. \\
\hline TP & $1,2,3,4,5$ & $<0.01$ & Sig. \\
\hline $\mathbf{U R E}$ & $1,2,3,4,5$ & $<0.01$ & Sig. \\
\hline ALB & $1,2,4$ & $<0.01$ & Sig. \\
\hline GLB & $1,2,4$ & $<0.01$ & Sig. \\
\hline CRT & $1,2,3,4,5$ & $<0.01$ & Sig. \\
\hline TG & $1,2,3,4,5$ & $<0.01$ & Sig. \\
\hline CLT & $1,2,3,4,5$ & $<0.01$ & Sig. \\
\hline GLC & $1,2,3,4,5$ & $<0.01$ & Sig. \\
\hline
\end{tabular}

SP: Serum Parameter, P: Difference, Sig.: Significant $\mathrm{P} \leq 0.05$ 
Worldwide, in a study conducted by Fiorentin et al. (2018), in DCs of western Santa Catarina (Brazil), results show a occurrence percentages of: $11 \%$ for subclinical hypocalcemia and $7.4 \%$ for subclinical hypomagnesemia. Even in United Kingdom, (UK) a recent survey carried out by Donadeu et al. (2020) show that both farmers and veterinarians ranked ketosis first, followed by hypocalcemia, acidosis, fatty liver disease and hypomagnesemia, as dominant metabolic disordes in UK. Main surveyed veterinarians (94.7\%) believed that the prevalence of metabolic disorders was a major issue on Fs in UK. Both farmers and veterinarians in UK recognized there were difficulties in diagnostic of metabolic subclinical disorders and that it become crucial to improve current diagnostic tools, particularly in regard to the need to detect diseases early. In the present study serum Mg level was not accessed. These facts corroborate to field constraints observed in Constantine Governorate, especially for the lack of diagnostic tools which tend to be very expensive, hurdling thus the performing of large surveys on cattle in all seasons and depending on several physiological stages of DCs.

\section{Statistical comparison of the serum parameters Ms for the whole Fs}

The comparison of the Ms via ANOVA test ( $\mathrm{p} \leq$ 0.05 ) for all Fs according to assessed parameters, showed that there is a high significant difference for the whole parameters throught Fs of the study area (Table 6). Regarding Algerian dairy farms, Boukhechem et al. (2019) report the fact of excessive use of dry hay and concentrates instead of silage and green fodder, the dominance of family farms and the relatively traditional farming methods, a lack in the "know-how" of herds managers, also a non compliance with the zootechnical standards in terms of comfort and ambient conditions.Concerning the present survey, some of these factors would explain the imbalances in results obtained for the surveyed Fs.

\section{Conclusion}

The study of partial metabolic profile in DCs of the five Fs in Constantine Governorate highlighted the existence of the following metabolic disorders: - moderate hypocalcemia (F1, F2, F3, F4);

- hyperphosphatemia was clear (F1, F2) and moderate (F3);
- moderate hypoproteinemia (F2, F5), moderate hyperproteinemia (F3, F4), hyperglobulinemia (F4) and hypourecimia (F2, F3);

- moderate hypocreatininemia (F1);

- hypertriglyceridemia (F1) and hypotriglyceridemia (F3, F4, F5);

- clear hypercholesterolemia in whole Fs.

- hypoglycemia (F4).

Also, significant differences had been shown from the comparison of one farm to another regarding the metabolic profiles during spring period, which suggest variability of management methods, feeding practices and DCs health status throught surveyed Fs within this period. The use of abnormal thresholds of some serum metabolites as risk factors is not sufficient to perform reliable prediction of the major relative disorders or pathologies rather than an indicator of suspicion which would require more detailed analyzes.

Acknowledgments. Authors acknowledge $\mathrm{Pr}$ Benlatreche Chérifa, chief Doctor of the biochemistry department at the University Hospital Center (CHU) of Constantine Governorate for her assistance as well as the technical staff of the biochemistry laboratory. Also, the veterinary Doctor Aimeur Mohamed for facilitating the investigations. Thanks to Mrs Rachel Susan Kayoueche-Phillips for reading and scrutinizing the text.

This research did not receive any specific grant from funding agencies in the public, commercial, or not-for-profit sectors.

\section{References}

1. Allen AJ (2015). Parturient paresis in cows (milk fever, hypocalcemia).In Disorders of Calcium Metabolism. Merck Veterinary Manual.https://www.merckvetmanual. com/ Accessed 09.04.20.

2. ANDI (National Agency for Investment Development, Algeria) (2013). Monography of Constantine Governorate.24 p. http://www.andi.dz/PDF/monographies/Constantine.pdf Accessed 28.03.20.

3. Ashmawy NA (2015). Blood metabolic profile and certain hormones concentrations in Egyptian buffalo during different physiological states. Asian Journal Animal Veterinary Advances, 10(6): 271-280. https:// doi.org/10.3923/ ajava.2015.271.280.

4. Bachir Pacha M, Triki-Yamani RR, Mohamed Said R (2016). The emergencies in bovine medicine: situation in the Region of the Centre of Algeria. Bulletin UASVM Veterinary Medicine, 73(1). 
5. Barnouin J, Chassagne M (1991).An aetiological hypothesis for the nutrition-induced association between retained placenta and milk fever in the dairy cow. Ann Rech Vet, 22 (4): 331- 43.

6. Barnouin J, Mialot M, Levieux D (1981).Evaluation de la pathologie hépatique des bovins sur un prélèvement de sang. Relation avec l'histopathologie.Ann Rech Vet, 12 (4): $363-69$.

7. Barnouin J, Paccard P (1988). Facteurs de risque nutritionnels de la pathologie hépatique dans les troupeaux bovins laitiers en France. Can Vet J, 29 (11): 915-20.

8. Benedet A, Franzoi M, Manuelian CL, Penasa M and De March M (2020). Variation of Blood Metabolites of Brown Swiss, Holstein-Friesian, and Simmental Cows. Animals, 10 (2): 271. DOI: 10.3390/ani10020271.Accessed 26.03.20.

9. Bobbo T, Ruegg PL, Fiore E, Gianesella M, Morgante M, Pasotto D, Gallo L, Bittante G and Cecchinato A (2017). Association between udder health status and blood serum proteins in dairy cows. Short communication. J Dairy Sci, 100: 9775-9780.

10. Boukhechem S., Mimoune N, Ghozlane MK, Moula N, Kaidi R (2019). Status, characterization and typology of dairy cattle farms in Northern Algeria. Bulletin UASVM Veterinary Medicine 76 (2)..

11. Bradford PS, Van Metre DC and Pusterla N (2020). Large Animal Internal Medicine.Sixth Edit.ELSEVIER.1878 p pp: $415-417$.

12. Braun JP, Bézille P and G. Rico A (1986). Biochemical semiology of the liver in ruminants.Reproduction, nutrition, development, 26: 227-43.

13. Brugere-Picoux J (1995). Biochimie clinique. La Dépêche Technique. Supplément technique à La Dépêche Vétérinaire, 46: 28-29.

14. Brugere -Picoux J (1984). Diagnostic des maladies métaboliques des vaches laitières. Chaire de pathologie du bétail et des animaux de basse- cour, $80 \mathrm{p}$.

15. Cai C, Kong Y, Wu D and Wang J (2018). Changes of macrominerals and calcitropic hormones in serum of periparturient dairy cows subject to subclinical hypocalcaemia. J Dairy Res, 85 (1): 12-15.

16. Chassagne M, Barnouin J, Chacornac JP (1998). Predictive markers in the late gestation period for retained placenta in black-pied dairy cows under field conditions in France. Theriogenology. 49 (3): 645-56.

17. Constable PD, Hinchcliff KW, Done SH, Grünberg W (2017). Diseases of the hemolymphatic and immune systems. In Veterinary Medicine (Eleventh Edition), W.B. Saunders, pp: 716 -844, ISBN 9780702052460.

18. Constable PD (2014). Left or right displaced abomasum and abomasal volvulus. In Diseases of the abobasum. Merck Veterinary Manual.https://www.merckvetmanual. com/. Accessed 09.04.20.

19. Coskun A, Aydogdu U, Guzelbektes H, Sen I (2020). The levels of trace elements and macrominerals in calves with sepsis. Kafkas Univ Vet Fak Derg, 26 (3): 351-355
20. DAS (Directory of Agriculture Services, Constantine) (2011). Rapport de statistiques sur l'évolution du cheptel bovin et de l'effectif des éleveurs de bovins enregistrés au niveau de wilaya de Constantine.

21. DAS (Directory of Agriculture Services, Constantine) (2015). Rapport de statistiques sur l'évolution du cheptel bovin et de l'effectif des éleveurs de bovins enregistrés au niveau de wilaya de Constantine.

22. Djoković RH, Samanc M, Petrović MD, Ilić Z, Kurćubić V (2012). Relationship among blood metabolites and lipid in the liver in transitional dairy cow. Biotechnology in animal husbandry, 28 (4): 705-714.

23. Donadeu FX, Howes NL, Esteves CL, Howes MP, Byrne TJ and Macrae AI (2020). Farmer and veterinary practices and opinions related to the diagnosis of mastitis and metabolic disease in UK dairy cows. Front Vet Sci, 7:127.

24. Eckersall PD (2000).Recent advances and future prospects for the use of acute phase proteins as markers of disease in animals.Rev. Méd. Vét, 151 (7): 577-584.

25. Ferrando R (1971).Profils biochimiques, sémiologie et élevage moderne. Cah. Méd, Vét, 40: 47-56.

26. Fiorentin EL, Zanovello S, Gato A, Piovezan AL, Alves MV, Rocha RX and Gonzalez F (2018). Occurrence of subclinical metabolic disorders in dairy cows from western Santa Catarina state, Brazil. Pesquisa Veterinária Brasileira, 38(4):629-634.

27. Foreman JH (2014). Hyperlipemia and hepatic lipidosis in large animals.In Production-related Metabolic Disorders, by Andrew J. Allen. Merck Veterinary Manual. https:// www.merckvetmanual.com/. Accessed 09.04.2020.

28. Gitelman HJ (1967). An improved automated procedure for the détermination of calcium in biological specimens. Anal Biochem, 18: 521-531.

29. Gourreau JM, Bendali F (2008). Maladies des bovins.4 ${ }^{\text {ème }}$ Ed.Paris (France), Editions France Agricole. 797 p. pp: 507-598.

30. Gruenberg W (2014). Hypophosphatemia. In Disorders of Phosphorus Metabolism. Merck Veterinary Manual. https://www.merckvetmanual.com/. Accessed 09.04.2020

31. Hadzimusic N, Krnic J (2012). Values of calcium, phosphorus and magnesium concentrations in blood plasma of cows in dependence on the reproductive cycle and season. J Fac Vet Med Istanbul Univ, 38 (1).

32. Haskell SRR (2008). Blackwell's Five-Minute Veterinary Consult: Ruminant. John Wiley \& Sons.1048 p, p: 45.

33. Jarrige R (1988).Alimentation des bovins, ovins et caprins. INRA Ed, Paris, $471 \mathrm{p}$.

34. Kalaitzakis E, Roubies N, Panousis N, Pourliotis K, Kaldrymidou E, Karatzias H (2006). Evaluation of ornithine carbamoyl transferase and other serum and liver-derived analytes in diagnosis of fatty liver and post-surgical outcome of left displaced adomasum in dairy cows. Journal of the American Veterinary Medical Association, 229 (9): 1463-1471.

35. Lorin B, Belli P, Frikha MR (2009). Cas clinique de médecine bovine: insuffisance rénale chez deux génisses 
Prim'Holstein due à une intoxication aux glands.Revue. Méd. Vet, 160 (11): 507-513.

36. MARD (Ministry of Agriculture and Rural Development, Algeria) (2014). Évaluation de la mise en œuvre des programmes du Renouveau Agricole. Campagne agricole 2014 (Pré Bilan)-Période 2009-2014.21 ème session d'évaluation trimestrielle - Alger, 11 et 13 Décembre $2014.19 \mathrm{p}$.

37. Molefe K and Mwanza M (2019). Serum biochemistry in cows of different breeds presented with reproductive conditions.Onderstepoort Journal of Veterinary Research 86 (1), a1742. https://doi.org/10.4102/ojvr. v86i1.1742.

38. Payne JM, Sally M, Manston R, Faulks M (1970).The use of metabolic profile test in dairy herds. Vet Rec, 87: 150-158.

39. Pelletier G, Tremblay A, Hélie P (1985). Facteurs influençant les profils métaboliques des vaches laitières. Can. Vet. J, 26: 306-311.

40. Qureshi MU, Qureshi MS, Khan R, Rahman A, Sohail SM, Asim I, Ijaz A, Shakoor A, Mohammad S and Basit A (2016). Relationship of blood metabolites with reproductive cyclicity in dairy cows.Indian Journal Of Animal Research, 50 (3): 338-348.

41. Robert SY, Threlfall WR (2007). Hypophosphatemia. In Current therapy in large animal theriogenology E-Book.2d Edit. SAUNDERS ELSEVIER Inc. pp: 362-363.

42. Rowlands GJ, Manston R, Stark AJ, Russell AM, Kollis KA, Collis SC (1980). Changes in albumin, globulin, glucose and cholesterol concentrations in the blood of dairy cows in late pregnancy and early lactation and relationships with subsequent fertility. J agric Sci Camb, 94: 517-527.
43. Sevinc M, Ok M, Basoglu A (2002). Liver function in dairy cows with abomasal displacement.Rev Méd Vét, 153 (7): 477- 480.

44. Soch M, Broucek J and Srejberova P (2010). Effect of selected factors on mineral parameters in plasma of cows. Archiv Tierzucht, 53 (5): 510-519.

45. Sommer H and Marx D (1969). Fertility of cattle and its relationship to metabolism. Preliminary report on blood serum values (GOT, LDH, bilirubin, cholesterol, glucose) and disposition endometritis. Berl Munch Tierarztl Wochenschr, 82(11):201-4.

46. Thrall MA, Weiser G, Allison R, Campbell T (2012). Veterinary hematology and clinical chemistry. John Wiley \& Sons Edit.784 p.

47. Underwood EJ and Suttle NF (1999). The mineral nutrition of livestock.3e Edition.Moredun Research Institute. CABI I Publishing.London. pp: 614.

48. Verite R, Retif S, Faverdin P (1995). L'urée du lait comme index de la qualité de la nutrition azotée et de l'excrétion d'azote chez la vache laitière en alimentation hivernale. Renc. Rech. Ruminants, 2: 365.

49. Verriele M, Bedouet J (1999). Les examens sanguins chez les bovins. Des clés pour utiliser la biochimie clinique. Le Point Vétérinaire, 30 (202): 25- 29.

50. Wolter R (1994).Alimentation de la vache laitière.Ed. France Agricole, Paris, $2^{\text {ème }}$ ed, 255 p.

51. Wolter R (1997).Alimentation de la vache laitière.Ed. France Agricole, Paris, $2^{\text {ème }}$ ed, 251 p.

52. Yokus B, Cakir UD (2006).Seasonal and physiological variations in serum chemistry and mineral concentrations in cattle. Biol Trace Elem Res, 109 (3): 255- 66. 